\title{
Role of Apoptosis in Microbial Infection
}

\author{
Faris Q. Alenzi ${ }^{*}$, Ahmed Q. Alotaibi2 ${ }^{2}$ Gdhi M. Almotiri², Anwar M. Alanazi2, \\ Faisal M. Alanazi², Mohammed S. Alenazi², Khalaf A. Alanazi², \\ Mohammed J. Alenzi ${ }^{3}$, Shamweel Y. Ahmad ${ }^{1}$ \\ ${ }^{1}$ Deparment of Medical Laboratory Sciences, College of Applied Medical Sciences, Salman Bin Abdulaziz \\ University, Al-Kharj, Saudi Arabia \\ ${ }^{2}$ Ministry of Health, Riyadh, Saudi Arabia \\ ${ }^{3}$ Medical College, Al-Jouf University, Sakaka, Saudi Arabia \\ Email: ${ }^{*}$ fqalenzi@ksu.edu.sa
}

Received 3 February 2014; revised 14 March 2014; accepted 25 March 2014

Copyright (C) 2014 by authors and Scientific Research Publishing Inc.

This work is licensed under the Creative Commons Attribution International License (CC BY).

http://creativecommons.org/licenses/by/4.0/

(c) (i) Open Access

\section{Abstract}

Apoptosis plays a central role in the pathogenesis of a number of human diseases. Because apoptosis represents a fundamental process in the response to such infections, it may represent a therapeutic target for their treatment. There is thus likely to be future clinical relevance in harnessing our growing knowledge both of apoptotic mechanisms, and their regulation, in the search to achieve modalities for therapeutic benefit. This brief review aims to summarize what we currently know about the role of apoptosis in response to a range of microbial infections (including bacterial and viral).

\section{Keywords}

\section{Apoptosis, Microbial Pathogens, Infection, Therapy}

\section{Introduction}

The consequences of innate immune recognition of host cells undergoing apoptosis as a direct result of infection remain somewhat unclear, even though the inflammatory phagocytosis of microbial pathogens and non-inflammatory phagocytosis of apoptotic cells have each been studied extensively. Following microbial infection the innate immune system is confronted with mixed signals, coming both from apoptotic cells and also those from the infecting pathogen. Nuclear receptor activation has been implicated downstream of apoptotic cell recognition while Toll-like receptors are the prototypical inflammatory receptors engaged during infection. When the two signals combine, a new set of events takes place, beginning with transrepression of a subset of inflam-

"Corresponding author. 
matory-response genes, and ending with the induction of a $\mathrm{T}$ helper-17 adaptive immune response. This response is best suited for clearing the infecting pathogen and repairing the damage that occurred to the host tissue during infection [1].

A wide variety of parasitic organisms (viruses, bacteria, fungi and protozoa) invade cells in order to exploit cellular resources and reproduce themselves, often killing infected host cells in the process. The progeny of such parasitic organisms then invade other, often nearby cells, which thus perpetuate the life cycle of the parasite. If a cell can detect that such an infection has occurred and that it is therefore fated to die, then by engaging a mechanism for more rapid cell death it will halt reproduction of the parasite and prevent its lethal spreading to other related cells (the most likely onward targets of a specialized parasite will usually be individual cells that closely resemble the initial cellular host). By this process, cells infected by a parasite may thus undergo apoptosis to prevent spreading of the infection to clone mates and other related vulnerable cells which assists with the wider aspects of survival of the entire organism. Active cell death in response to infection essentially thus becomes one of the earliest types of immunity. Since host-parasite interactions are dynamic, parasites evolve mechanisms to prevent such active cell death, and thereby promote their own survival and ability for replication.

At present, there is no evidence that strongly supports the presence of a molecular pathway mediating apoptosis in unicellular organisms that is triggered in response to infection. Some protists have been observed to undergo cell death with the superficial characteristics of apoptosis [2]-[6], but it remains to be seen whether the mechanisms are related to those of metazoans. Nevertheless, using the principles of parsimony and Occam's razor, by comparing organisms in different phyla (or kingdoms) conclusions can be drawn about the characteristics of cell death in common ancestors. As we learn more about the pathways of apoptosis in diverse organisms, these APOPTOTIC AND NECROTIC Macrophages are independently regulated during $M$. tuberculosis infection of macrophages. Virulence affects the level of host cell death and the ability to inhibit apoptosis, whilst other strain-specific characteristics influence the ultimate mode of host cell death and alter the balance of apoptosis and necrosis [7].

\section{Apoptosis and Bacterial Infection}

M. tuberculosis-infected macrophages can undergo two general modes of cell death: apoptosis and necrosis. These two forms of cell death appear to have drastically different outcomes for the course of infection. Apoptosis (programmed cell death) is an energy-dependent process mediated by the caspase cascade, and which results in the ordered degradation of cellular contents and the formation of apoptotic vesicles. It has been demonstrated that apoptotic cell death of M. tuberculosis-infected macrophages is directly associated with mycobacterial killing [8]-[12] and can also enhance stimulation of T-cell responses via the "detour" pathway of antigen presentation [13]-[15]. On the other hand, necrotic cell death, is associated with a disordered, energy independent death of the cell, although recent work suggests that necrosis can also follow a strictly programmed and ordered series of events [16] [17]. In M. tuberculosis infection, a necrosis-like form of death has been observed and demonstrated to allow the release of viable mycobacteria for subsequent re-infection [11] [18]. Necrotic cell death may be an important factor in granuloma formation, inflammatory tissue damage and ultimately transmission of the bacterium.

Several studies have suggested that pathogenic M. tuberculosis strains use inhibition of apoptosis as a virulence mechanism, and that the effects are dependent on multiplicity of infection and relative virulence of the mycobacterial strain. Keane et al. demonstrated that, at low multiplicities of infection, virulent $M$. tuberculosis induced less macrophage apoptosis than attenuated M. tuberculosis complex organisms or saprophytic mycobacteria [19]. Conversely, higher multiplicities of infection with $\mathrm{M}$. tuberculosis resulted in necrosis-like cell death through a caspase-independent mechanism [20] [21] and several studies report that virulent strains of $M$. tuberculosis induce necrotic death of the macrophage [22]-[25]. Hence it has become a popular model that virulent M. tuberculosis inhibits apoptosis, whereas avirulent mycobacteria stimulate apoptosis. Furthermore, individual $M$. tuberculosis genes involved in apoptosis inhibition have been discovered, such as nuoG and secA2 [26] [27] and deletion of these genes is reported to result in a "pro-apoptotic" phenotype.

Salmonella enterica is an important enteric pathogen of humans and of a variety of domestic and wild animals. It can produce both localized enteritis and disseminated systemic disease in humans and in a variety of other vertebrates [28] Salmonella strains can also disseminate from the intestine and produce serious, sometimes fatal infections with considerable cytopathology in a number of systemic organs. A combination of bacterial genetic 
and cell biology studies have shown that Salmonella uses specific virulence mechanisms to induce host cell death during infection. Salmonella produces one set of virulence proteins to promote invasion of the intestine and a different set to mediate systemic disease. Significantly, each set of virulence factors mediates a distinct mechanism of host cell death. The Salmonella pathogenicity island-1 (SPI-1) locus encodes a type III protein secretion system (TTSS) that delivers effector proteins required for intestinal invasion and the production of enteritis [29]. The SPI-1 effector SipB activates caspase-1 in macrophages, which causes release of IL-1b and IL-18 and induces rapid cell death by a mechanism that has features of both apoptosis and necrosis. Caspase- 1 is required for Salmonella to infect Peyers patches and disseminate to systemic tissues in mice. Progressive Salmonella infection in mice requires the SPI-2 TTSS and associated effector proteins as well as the SpvB cytotoxin. Apoptosis of macrophages in the liver is found during systemic infection [29].

Bacterial pathogens can induce apoptosis or necrosis by a variety of direct and indirect mechanisms [30]. In many pathogenesis studies, a comprehensive analysis of the mechanism of cell death due to bacterial infection has not been undertaken. Instead, the process has been reported as necrosis or apoptosis based on the use of one or a small number of cell biology markers. Occasionally, a mixed process has been described by terms such as “oncosis” [31] (or ischaemic cell death), and "programmed necrosis” [32] [33].

\section{Apoptosis and Viral Infection}

Apoptosis of host cells can also result from viral infection whether by induction of tumor necrosis factor, contradictory signals involving cell growth, or direct viral cytotoxicity. While adenovirus and influenza viruses cause apoptosis, some viruses (such as baculovirus) may inhibit apoptosis.

Chronic HCV infection differently modulates the apoptotic machinery during the course of infection, where the virus induces apoptosis early in the course of infection, and as the disease progresses apoptosis is modulated [34]. Although the exact mechanisms of HCV pathogenesis, such as viral persistence, hepatocyte injury, and hepatocarcinogenesis are not fully understood, nevertheless an accumulating body of evidence suggests that apoptosis of hepatocytes is significantly involved in the pathogenesis [35] [36]. Apoptosis plays a pivotal role in the maintenance of cellular homeostasis through removal of aged cells, damaged cells, and overgrowing new cells [37].

Reovirus infection has proven to be an excellent experimental system for studying mechanisms of virus-induced pathogenesis. Reoviruses induce apoptosis in a wide variety of cultured cells in vitro and in target tissues in vivo, including the heart and CNS [38]. In vivo, viral infection, tissue injury, and apoptosis co-localize, suggesting that apoptosis is a critical mechanism by which disease is triggered in the host [39]-[41]. Several reviews examine the mechanisms of reovirus-induced apoptosis and investigate the possibility that inhibition of apoptosis may provide a novel strategy for limiting virus-induced tissue damage following infection.

Two factors, p35 gene and inhibitor of apoptosis (IAP), found in baculovirus can also inhibit apoptosis in a response to large number of triggers [42] [43]. Baculovirus, Pox virus and cowpox gene crm-A attenuate apoptosis by inhibiting IL-1 converting enzyme (ICE) [44]. Furthermore, crm-A also inhibits the inflammatory response to viral infection and thus, by doing so, promotes the viral pathogenic process [44] [45]. Viral latency also represents an important factor. For example, in EBV infection, the viral gene LMP-1 is expressed during latency, which then upregulates Bcl-2 expression, which creates a beneficial survival environment to latency infected cells [46]. Furthermore, apoptosis-sensitive B cell lines can be made resistant to cell death by transfection of LMP-1 [47].

Apoptosis can sometimes occur in severe acute respiratory syndrome (SARS). When this occurs, the invasive cells in the affected tissues are primarily monocytes, which suggests that invasion of monocytes (and apoptosis) may play an important role in the progression of SARS. Furthermore, evidence that the SARS virus may have an immune-relevant cell-killing effect during its pathogenesis arises from the observation of a decreased number of $\mathrm{T}$ cells and $\mathrm{B}$ cells in the lungs and $\mathrm{CD} 4^{+} \mathrm{CD}^{+} \mathrm{T}$ cells and $\mathrm{CD} 20^{+} / \mathrm{CD}_{4} 5 \mathrm{RA}^{+} \mathrm{B}$ cells in the spleen and lymph nodes [48].

\section{Apoptosis and AIDS}

The pathogenesis of AIDS may involve inappropriate induction of $\mathrm{CD} 4^{+} \mathrm{T}$ cell apoptosis by HIV [49]. The viral transcription gene-Tat influences mRNA transcription of some genes involved in cell survival. Furthermore, the Tat gene has been shown to upregulate the expression of Bcl-2 oncogenic protein, which suggests that it may 
protect cells from apoptosis [50]. Peripheral blood T cells from HIV-infected individuals have long been known to be highly sensitive to in vitro-induced cell death, and the incubation of T cells from HIV patients rapidly triggers apoptosis [51]-[53], accelerated even further by a range of inducers, including mitogens. Superantigens also considerably increase the number of apoptotic cells [51] [54]. T cells from lymph nodes, and peripheral blood, of HIV patients express both tissue transglutaminase (tTG) and a $\mathrm{Ca}^{2+}$-independent enzyme, factors that appear to be important in the pre-apoptotic process [55]. It was originally felt that CD4 subset was primed for apoptosis in HIV infections, but the CD8 subset may also be involved [56]. It has been observed that activated T lymphocytes expressing CD45RO, HLA-DR, CD38 are more prone to apoptosis compared with controls [57] [58].

Histopathology of lymph nodes and thymus of HIV-infected individuals has demonstrated that apoptosis takes place not only in infected cells, but also in their neighboring cells [59]. Ex-vivo experiments have concurred with these observations by showing that approximately $50 \%$ of peripheral blood lymphocytes from HIV-infected individuals undergo apoptosis [60].

\section{Conflict of Interest}

The authors declare no conflict of interest.

\section{References}

[1] Torchinsky, M.B., Garaude, J. and Blander, J.M. (2010) Infection and Apoptosis as a Combined Inflammatory Trigger. Current Opinion in Immunology, 22, 55-62. http://dx.doi.org/10.1016/j.coi.2010.01.003

[2] Ameisen, J.C., Idziorek, T., Billaut-Mulot, O., Loyens, M., Tissier, J.P., Potentier, A. and Ouaissi, A. (1995) Apoptosis in a Unicellular Eukaryote (Trypanosoma cruzi): Implications for the Evolutionary Origin and Role of Programmed Cell Death in the Control of Cell Proliferation, Differentiation and Survival. Cell Death \& Differentiation, 2, 285-300.

[3] Christensen, S.T., Wheatley, D.N., Rasmussen, M.I. and Rasmussen, L. (1995) Mechanisms Controlling Death, Survival and Proliferation in a Model Unicellular Eukaryote Tetrahymena thermophila. Cell Death \& Differentiation, 2, 301-308.

[4] Cornillon, S., Foa, C., Davoust, J., Buonavista, N., Gross, J.D. and Golstein, P. (1994) Programmed Cell Death in Dictyostelium. Journal of Cell Science, 107, 2691-2704.

[5] Piacenza, L., Peluffo, G. and Radi, R. (2001) L-Arginine-Dependent Suppression of Apoptosis in Trypanosoma cruzi: Contribution of the Nitric Oxide and Polyamine Pathways. Proceedings of the National Academy of Sciences, 98, 7301-7306. http://dx.doi.org/10.1073/pnas.121520398

[6] Welburn, S.C., Dale, C., Ellis, D., Beecroft, R. and Pearson, T.W. (1996) Apoptosis in Procyclic Trypanosoma brucei Rhodesiense in Vitro. Cell Death \& Differentiation, 3, 229-236.

[7] Butler, R.E., Brodin, P., Jang, J., Jang, M.S., Robertson, B.D., Gicquel, B. and Stewart, G.R. (2012) The Balance of Apoptotic and Necrotic Cell Death in Mycobacterium tuberculosis Infected Macrophages Is Not Dependent on Bacterial Virulence. PLoS one, 7, Article ID: e47573. http://dx.doi.org/10.1371/journal.pone.0047573

[8] Lopez, M., Sly, L.M., Luu, Y., Young, D. and Cooper, H. (2003) The 19-kDa Mycobacterium tuberculosis Protein Induces Macrophage Apoptosis through Toll-Like Receptor-2. Journal of Immunology, 170, 2409-2416.

[9] Oddo, M., Renno, T., Attinger, A., Bakker, T., MacDonald, H.R. and Meylan, P.R. (1998) Fas Ligand-Induced Apoptosis of Infected Human Macrophages Reduces the Viability of Intracellular Mycobacterium tuberculosis. Journal of Immunology, 160, 5448-5454.

[10] Lammas, D.A., Stober, C., Harvey, C.J., Kendrick, N., Panchalingam, S. and Kumararatne, D.S. (1997) ATP-Induced Killing of Mycobacteria by Human Macrophages Is Mediated by Purinergic P2Z(P2X7) Receptors. Immunity, 7, 433444. http://dx.doi.org/10.1016/S1074-7613(00)80364-7

[11] Molloy, A., Laochumroonvorapong, P. and Kaplan, G. (1994) Apoptosis, But Not Necrosis, of Infected Monocytes Is Coupled with Killing of Intracellular Bacillus Calmette-Guerin. Journal of Experimental Medicine, 180, 1499-1509. http://dx.doi.org/10.1084/jem.180.4.1499

[12] Thoma-Uszynski, S., Stenger, S., Takeuchi, O., Ochoa, M.T., Engele, M., Sieling, P.A., Barnes, P.F., Rollinghoff, M., Bolcskei, P.L., Wagner, M., Akira, S., Norgard, M.V., Belisle, J.T., Godowski, P.J., Bloom, B.R. and Modlin, R.L. (2001) Induction of Direct Antimicrobial Activity through Mammalian Toll-Like Receptors. Science, 291, 1544-1547. http://dx.doi.org/10.1126/science.291.5508.1544

[13] Schaible, U.E., Winau, F., Sieling, P.A., Fischer, K., Collins, H.L., Hagens, K., Modlin, R.L., Brinkmann, V. and Kaufmann, S.H. (2003) Apoptosis Facilitates Antigen Presentation to T Lymphocytes through MHC-I and CD1 in Tu- 
berculosis. Nature Medicine, 9, 1039-1046. http://dx.doi.org/10.1038/nm906

[14] Winau, F., Kaufmann, S.H. and Schaible, U.E. (2004) Apoptosis Paves the Detour Path for CD8 T Cell Activation against Intracellular Bacteria. Cellular Microbiology, 6, 599-607. http://dx.doi.org/10.1111/j.1462-5822.2004.00408.X

[15] Winau, F., Weber, S., Sad, S., de Diego, J., Hoops, S.L., Breiden, B., Sandhoff, K., Brinkmann, V., Kaufmann, S.H. and Schaible, U.E. (2006) Apoptotic Vesicles Crossprime CD8 T Cells and Protect against Tuberculosis. Immunity, 24, 105-117. http://dx.doi.org/10.1016/j.immuni.2005.12.001

[16] Golstein, P. and Kroemer, G. (2007) Cell Death by Necrosis: Towards a Molecular Definition. Trends in Biochemical Sciences, 32, 37-43. http://dx.doi.org/10.1016/j.tibs.2006.11.001

[17] Cho, Y.S., Challa, S., Moquin, D., Genga, R., Ray, T.D., Guildford, M. and Chan, F.K. (2009) Phosphorylationdriven Assembly of the RIP1-RIP3 Complex Regulates Programmed Necrosis and Virus-Induced Inflammation. Cell, 137, 1112-1123. http://dx.doi.org/10.1016/j.cell.2009.05.037

[18] Lee, J., Repasy, T., Papavinasasundaram, K., Sassetti, C. and Kornfeld, H. (2011) Mycobacterium tuberculosis Induces an Atypical Cell Death Mode to Escape from Infected Macrophages. PLoS ONE, 6, Article ID: e18367. http://dx.doi.org/10.1371/journal.pone.0018367

[19] Keane, J., Remold, H.G. and Kornfeld, H. (2000) Virulent Mycobacterium Tuberculosis Strains Evade Apoptosis of Infected Alveolar Macrophages. Journal of Immunology, 164, 2016-2020.

[20] O’Sullivan, M.P., O’Leary, S., Kelly, D.M. and Keane, J. (2007) A Caspase-Independent Pathway Mediates Macrophage Cell Death in Response to Mycobacterium Tuberculosis Infection. Infection and Immunity, 75, 1984-1993. http://dx.doi.org/10.1128/IAI.01107-06

[21] Lee, J., Remold, H.G., Ieong, M.H. and Kornfeld, H. (2006) Macrophage Apoptosis in Response to High Intracellular Burden of Mycobacterium Tuberculosis Is Mediated by a Novel Caspase-Independent Pathway. Journal of Immunology, 176, 4267-4274.

[22] Park, J.S., Tamayo, M.H., Gonzalez-Juarrero, M., Orme, I.M. and Ordway, D.J. (2006) Virulent Clinical Isolates of Mycobacterium tuberculosis Grow Rapidly and Induce Cellular Necrosis but Minimal Apoptosis in Murine Macrophages. Journal of Leukocyte Biology, 79, 80-86. http://dx.doi.org/10.1189/jlb.0505250

[23] Chen, M., Gan, H. and Remold, H.G. (2006) A Mechanism of Virulence: Virulent Mycobacterium Tuberculosis Strain H37Rv, but Not Attenuated H37Ra, Causes Significant Mitochondrial Inner Membrane Disruption in Macrophages Leading to Necrosis. Journal of Immunology, 176, 3707-3716.

[24] Zhang, J., Jiang, R., Takayama, H. and Tanaka, Y. (2005) Survival of Virulent Mycobacterium tuberculosis Involves Preventing Apoptosis Induced by Bcl-2 Upregulation and Release Resulting from Necrosis in J774 Macrophages. Microbiology and Immunology, 49, 845-852. http://dx.doi.org/10.1111/j.1348-0421.2005.tb03673.X

[25] Sohn, H., Lee, K.S., Kim, S.Y., Shin, D.M., Shin, S.J., Jo, E.K., Park, J.K. and Kim, H.J. (2009) Induction of Cell Death in Human Macrophages by a Highly Virulent Korean Isolate of Mycobacterium tuberculosis and the Virulent Strain H37Rv. Scandinavian Journal of Immunology, 69, 43-50. http://dx.doi.org/10.1111/j.1348-0421.2005.tb03673.X

[26] Velmurugan, K., Chen, B., Miller, J.L., Azogue, S., Gurses, S., Hsu, T., Glickman, M., Jacobs Jr., W.R., Porcelli, S.A. and Briken, V. (2007) Mycobacterium tuberculosis nuoG Is a Virulence Gene That Inhibits Apoptosis of Infected Host Cells. PLOS Pathogens, 3, Article ID: e110. http://dx.doi.org/10.1371/journal.ppat.0030110

[27] Hinchey, J., Lee, S., Jeon, B.Y., Basaraba, R.J., Venkataswamy, M.M., Chen, B., Chan, J., Braunstein, M., Orme, I.M., Derrick, S.C., Morris, S.L., Jacobs Jr., W.R. and Porcelli, S.A. (2007) Enhanced Priming of Adaptive Immunity by a Proapoptotic Mutant of Mycobacterium tuberculosis. Journal of Clinical Investigation, 117, 2279-2288. http://dx.doi.org/10.1172/JCI31947

[28] Ohl, M.E. and Miller, S.I. (2001) Salmonella: A Model for Bacterial Pathogenesis. Annual Review of Medicine, 52, 259-274.

[29] Galán, J.E. (2001) Salmonella Interactions with Host Cells: Type III Secretion at Work. Annual Review of Cell and Developmental Biology, 17, 53-86. http://dx.doi.org/10.1146/annurev.cellbio.17.1.53

[30] Weinrauch, Y. and Zychlinsky, A. (1999) The Induction of Apoptosis by Bacterial Pathogens. Annual Review of Microbiology, 53, 155-187. http://dx.doi.org/10.1146/annurev.micro.53.1.155

[31] Majno, G. and Joris, I. (1995) Apoptosis, Oncosis, and Necrosis. An Overview of Cell Death. American Journal of Pathology, 146, 3-15.

[32] Hernandez, L.D., Pypaert, M., Flavell, R.A. and Galan, J.E. (2003) A Salmonella Protein Causes Macrophage Cell Death by Inducing Autophagy. Journal of Cell Biology, 163, 1123-1131. http://dx.doi.org/10.1083/jcb.200309161

[33] Guimarães, C.A. and Linden, R. (2004) Programmed Cell Deaths. Apoptosis and Alternative Deathstyles. European Journal of Biochemistry, 271, 1638-1650. http://dx.doi.org/10.1111/j.1432-1033.2004.04084.X

[34] Zekri, A.R., Bahnassy, A.A., Hafez, M.M., Hassan, Z.K., Kamel, M., Loutfy, S.A., Sherif, G.M., El-Zayadi, A.R. and 
Daoud, S.S. (2011) Characterization of Chronic HCV Infection-Induced Apoptosis. Comparative Hepatology, 10, 4. http://dx.doi.org/10.1186/1476-5926-10-4

[35] Fischer, R., Baumert, T. and Blum, H.E. (2007) Hepatitis C Virus Infection and Apoptosis. World Journal of Gastroenterology, 13, 4865-4872.

[36] Mankouri, J., Dallas, M.L., Hughes, M.E., Griffin, S.D., Macdonald, A., Peers, C. and Harris, M. (2009) Suppression of a Pro-Apoptotic K+ Channel as a Mechanism for Hepatitis C Virus Persistence. Proceedings of the National Academy of Sciences of the United States of America, 106, 15903-15908. http://dx.doi.org/10.1073/pnas.0906798106

[37] Shin, E.C., Shin, J.S., Park, J.H., Kim, J.J., Kim, H. and Kim, S.J. (1998) Expression of Fas-Related Genes in Human Hepatocellular Carcinomas. Cancer Letters, 134, 155-162. http://dx.doi.org/10.1016/S0304-3835(98)00251-1

[38] Clarke, P. and Tyler, K.L. (2003) Reovirus-Induced Apoptosis: A Minireview. Apoptosis, 8, 141-150. http://dx.doi.org/10.1023/A:1022966508671

[39] DeBiasi, R.L., Edelstein, C.L., Sherry, B. and Tyler, K.L. (2000) Calpain Inhibition Protects against Virus-Induced Apoptotic Myocardial Injury. Journal of Virology, 75, 351-361. http://dx.doi.org/10.1128/JVI.75.1.351-361.2001

[40] Oberhaus, S.M., Smith, R.L., Clayton, G.H., Dermody, T.S. and Tyler, K.L. (1997) Reovirus Infection and Tissue Injury in the Mouse Central Nervous System Are Associated with Apoptosis. Journal of Virology, 71, 2100-2106.

[41] Richardson-Burns, S.M., Kominsky, D.J. and Tyler, K.L. (2002) Reovirus-Induced Neuronal Apoptosis is Mediated by Caspase 3 and Is Associated with the Activation of Death Receptors. Journal of Neurovirology, 8, 365-380. http://dx.doi.org/10.1080/13550280260422677

[42] Clem, R.J., Fechheimer, M. and Miller, L.K. (1991) Prevention of Apoptosis by a Baculovirus Gene during Infection of Insect Cells. Science, 254, 1388-1390. http://dx.doi.org/10.1126/science.1962198

[43] Sugimoto, A., Friesen, P.D. and Rothman, J.H. (1994) Baculovirus p35 Prevents Developmentally Programmed Cell Death and Rescues a Ced-9 Mutant in the Nematode Caenorhabditis Elegans. EMBO Journal, 13, 2023-2028.

[44] Ray, C.A., Black, R.A., Kronheim, S.R., Greenstreet, T.A., Sleath, P.R., Salvesen, G.S. and Pickup, D.J. (1992) Viral Inhibition of Inflammation: Cowpox Virus Encodes an Inhibitor of the Interleukin-1 Beta Converting Enzyme. Cell, 69, 597-604.

[45] Gagliardini, V., Fernandez, P.A., Lee, R.K., Drexler, H.C., Rotello, R.J., Fishman, M.C. and Yuan, J. (1994) Prevention of Vertebrate Neuronal Death by the crmA Gene. Science, 263, 826-828. http://dx.doi.org/10.1126/science.8303301

[46] Henderson, S., Rowe, M., Gregory, C., Croom-Carter, D., Wang, F., Longnecker, R., Kieff, E. and Rickinson, A. (1991) Induction of bcl-2 Expression by Epstein-Barr Virus Latent Membrane Protein 1 Protects Infected B Cells from Programmed Cell Death. Cell, 65, 1107-1115.

[47] Gregory, C.D., Dive, C., Henderson, S., Smith, C.A., Williams, G.T., Gordon, J. and Rickinson, A.B. (1991) Activation of Epstein-Barr Virus Latent Genes Protects Human B Cells from Death by Apoptosis. Nature, 349, 612-614. http://dx.doi.org/10.1038/349612a0

[48] Zhang, Q., Ding, Y., He, L., Wang, W., Zhang, J., Wang, H., Cai, J., Geng, J., Lu, Y. and Luo, Y. (2003) Detection of Cell Apoptosis in the Pathological Tissues of Patients with SARS and Its Significance. Di Yi Jun Yi Da Xue Xue Bao, 23, 770-773.

[49] Sabri, F., Titanji, K., De Milito, A. and Chiodi, F. (2003) Astrocytes Activation and Apoptosis: Their Roles in the Neuropathology of HIV Infection. Brain Pathology, 13, 84-94. http://dx.doi.org/10.1111/j.1750-3639.2003.tb00009.x

[50] Zauli, G., Gibellini, D., Caputo, A., Bassini, A., Negrini, M., Monne, M., Mazzoni, M. and Capitani, S. (1995) The Human Immunodeficiency Virus Type-1 Tat Protein Upregulates Bcl-2 Gene Expression in Jurkat T-Cell Lines and Primary Peripheral Blood Mononuclear Cells. Blood, 86, 3823-3834.

[51] Gougeon, M.L., Olivier, R., Garcia, S., Guetard, D., Dragic, T., Dauguet, C. and Montagnier, L. (1991) Demonstration of an Engagement Process towards Cell Death by Apoptosis in Lymphocytes of HIV Infected Patients. Comptes Rendus de l Académie des Sciences-Series III, 312, 529-537. (in French)

[52] Meyaard, L., Otto, S.A., Jonker, R.R., Mijnster, M.J., Keet, R.P. and Miedema, F. (1992) Programmed Death of T Cells in HIV-1 Infection. Science, 257, 217-219.

[53] Meyaard, L., Otto, S.A., Schuitemaker, H. and Miedema, F. (1992) Effects of HIV-1 Tat Protein on Human T Cell Proliferation. European Journal of Immunology, 22, 2729-2732. http://dx.doi.org/10.1002/eji.1830221038

[54] Groux, H., Torpier, G., Monte, D., Mouton, Y., Capron, A. and Ameisen, J.C. (1992) Activation-Induced Death by Apoptosis in CD4+ T Cells from Human Immunodeficiency Virus-Infected Asymptomatic Individuals. Journal of Experimental Medicine, 175, 331-340. http://dx.doi.org/10.1084/jem.175.2.331

[55] Amendola, A., Gougeon, M.L., Poccia, F., Bondurand, A., Fesus, L. and Piacentini, M. (1996) Induction of “Tissue” Transglutaminase in HIV Pathogenesis: Evidence for High Rate of Apoptosis of CD4+ T Lymphocytes and Accessory 
Cells in Lymphoid Tissues. Proceedings of the National Academy of Sciences of the United States of America, 93, 11057-11062. http://dx.doi.org/10.1073/pnas.93.20.11057

[56] van Noesel, C.J., Gruters, R.A., Terpstra, F.G., Schellekens, P.T., van Lier, R.A. and Miedema, F. (1990) Functional and Phenotypic Evidence for a Selective Loss of Memory T Cells in Asymptomatic Human Immunodeficiency VirusInfected Men. Journal Clinical Investigation, 86, 293-299. http://dx.doi.org/10.1172/JCI114698

[57] Meyaard, L., Otto, S.A., Keet, I.P., Roos, M.T. and Miedema, F. (1994) Programmed Death of T Cells in Human Immunodeficiency Virus Infection. No Correlation with Progression to Disease. Journal Clinical Investigation, 93, 982988. http://dx.doi.org/10.1172/JCI117105

[58] Gougeon, M.L., Lecoeur, H., Dulioust, A., Enouf, M.G., Crouvoiser, M., Goujard, C., Debord, T. and Montagnier, L. (1996) Programmed Cell Death in Peripheral Lymphocytes from HIV-Infected Persons: Increased Susceptibility to Apoptosis of CD4 and CD8 T Cells Correlates with Lymphocyte Activation and with Disease Progression. Journal of Immunology, 156, 3509-3520.

[59] Finkel, T.H., Tudor-Williams, G., Banda, N.K., Cotton, M.F., Curiel, T., Monks, C., Baba, T.W., Ruprecht, R.M. and Kupfer, A. (1995) Apoptosis Occurs Predominantly in Bystander Cells and Not in Productively Infected Cells of HIVand SIV-Infected Lymph Nodes. Nature Medicine, 1, 129-134. http://dx.doi.org/10.1038/nm0295-129

[60] Oyaizu, N., McCloskey, T.W., Coronesi, M., Chirmule, N., Kalyanaraman, V.S. and Pahwa, S. (1993) Accelerated Apoptosis in Peripheral Blood Mononuclear Cells (PBMCs) from Human Immunodeficiency Virus Type-1 Infected Patients and in CD4 Cross-Linked PBMCs from Normal Individuals. Blood, 82, 3392-400. 